\section{PELATIHAN \\ MERANCANG ASESMEN \\ HASIL BELAJAR DI LBB \\ TAMAN PINTAR \\ LAMONGAN}

Hadi Suryanto', Yayuk Chayatun Machsunah $^{2}$, Ratna Nurdiana ${ }^{3}$

1,2,3 Universitas PGRI Adi Buana Surabaya

*Hadi Suryanto

Email : hsuryanto3@gmail.com

\begin{abstract}
The Learning Guidance Institute (LBB) Taman Pintar Lamongan is a non-formal educational institution. Even though it is non-formal education, the assessment of learning outcomes for students must still be considered like formal education. The choice of Taman Pintar as a place for Community Service for us lecturers at PGRI Adi Buana University, Lamongan Campus, is inseparable because Taman Pintar is an institution that uses graduates on our campus as tutors in the last 10 years. Keywords: ; training, assessment, tutor
\end{abstract}

\begin{abstract}
Abstrak
Lembaga Bimbingan Belajar (LBB) Taman Pintar Lamongan merupakan lembaga pendidikan non formal. Walaupun pendidikan non formal tetapi assessment hasil belajar bagi siswa tetap harus diperhatikan layaknya pendidikan formal. Dipilihnya Taman Pintar sebagai tempat Pengabdian Masyarakat bagi kami dosen Universitas PGRI Adi Buana Kampus Lamongan ini tidak terlepas karena Taman Pintar merupakan lembaga pengguna lulusan di kampus kami sebagai tutor dalam 10 tahun terakhir.

Kata Kunci: pelatihan, assesmen, tutor
\end{abstract}


Pelatihan Merancang Asesmen Hasil Belajar di LBB Taman Pintar Lamongan

Hadi Suryanto, Yayuk Chayatun Machsunah, Ratna Nurdiana

Vol. 1, No. 2, Agustus 2021 hal. 123-129

DOI Artikel : 10.46306/jub.v1i2.27

\section{PENDAHULUAN}

Pengukuran hasil belajar harus dilakukan dengan cermat untuk mempresentasikan keadaan yang sebenarnya. Begitu juga terhadap Lembaga Bimbingan Belajar (LBB) Taman Pintar, Sahabat Sekolah Anak yang termasuk dalam pendidikan non formal. Tetapi dalam pembelajaran, tutor (pembelajar) menggunakan assessment untuk mengetahui capaian pembelajaran seperti halnya pada pendidikan formal. Sebagai seorang Tutor disamping melakukan bimbingan belajar juga harus mampu melakukan asesmen hasil belajar untuk mengetahui tingkat capaian pembalajaran yang diharapkan dengan kondisi pembelajar di lapangan. Penilaian yang relevan dengan tujuan pembelajaran dapat mengungkap hasil belajar dengan baik, hal ini dilakukan denga mempertimbangkan materi pembelajaran, tujuan pembelajaran dan karakteristik peserta didik (Baxter \& John, 202I; Suryanto, Degeng, Djatmika, \& Kuswandi, 2020). Beberapa kegiatan didalam melakukan asesmen yaitu $(I)$ tes merupakan kegiatan menjawab soal-soal yang diberikan, (2) Pengukuran merupakan kegiatan membandingkan hasil jawaban dengan standar baku, dan (3) penilaian yaitu kegiatan membandingkan nilai yang diperoleh dengan dengan standar minimum yang seharusnya diperoleh. asesmen adalah sebagai proses untuk mendapatkan informasi dalam bentuk apapun yang bisa digunakan untuk dasar pengambilan keputusan yang terkait dengan siswa baik yang menyangkut kurikulumnya, program pembelajarannya, iklim sekolah serta kebijakan-kebijakan sekolah (Kipman, Kühberger, \& Pletzer, 2019). disebutkan 5 kemampuan pokok guru yaitu kemampuan untuk: (1) merumuskan indikator keberhasilan belajar, (2) memilih dan mengorganisasikan materi, (3) memilih sumber belajar, (4) memilih mengajar dan (5) melakukan penilaian (Endang \& dkk, 2008). Pengukuran merupakan kuantifikasi atau penetapan angka tentang karakteristik atau keadaan individu menurut aturanaturan tertentu (Widoyoko, 20I4).

Secara rinci fungsi dari penilaian kelas yaitu: a. Kalau tujuan pembelajaran adalah pencapaian standar kompetensi maupun kompetensi dasar, maka penilaian kelas ini dapat menggambarkan sejauhmana seorang peserta didik telah menguasai suatu kompetensi. b. Asesmen berbasis kelas dapat berfungsi pula sebagai landasan pelaksanaan evaluasi hasil belajar peserta didik dalam rangka membantu peserta didik memahami dirinya, membuat keputusan tentang langkah berikutnya, baik untuk pemilihan program, pengembangan kepribadian maupun untuk penjurusan, dalam hal ini terkait erat dengan peran guru sebagai pendidik sekaligus pembimbing. c. Sejalan dengan tujuan asesmen yang telah dikemukakan di atas maka salah satu fungsi asesmen berbasis kelas ini adalah menemukan kesulitan belajar dan kemungkinan prestasi yang bisa dikembangkan peserta didik dan sebagai alat diagnosis yang membantu pendidik menentukan apakah seorang siswa perlu mengikuti remedial atau justru memerlukan program pengayaan. d. Dengan demikian asesmen juga akan berfungsi sebagai upaya pendidik untuk dapat menemukan kelemahan dan kekurangan proses pembelajaran yang telah dilakukan ataupun yang sedang berlangsung. Temuan ini selanjutnya dapat digunakan sebagai dasar penentuan langkah perbaikan proses pembelajaran berikutnya, guna peningkatan capaian hasil belajar siswa . e. Kesemuanya dapat dipakai sebagai kontrol bagi guru sebagai pendidik dan semua stake holder pendidikan dalam lingkup sekolah tentang gambaran kemajuan perkembangan proses dan hasil belajar peserta didik (Diknas, 2006).

\section{METODE PENGABDIAN} berikut :

Dalam pelatihan ini metode yang dilakukan terdiri dari beberapa kegiatan dengan tahapan sebagai

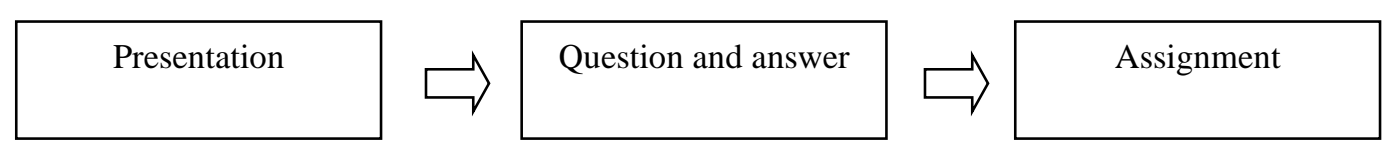




\section{Presentation (pemaparan)}

Pada tahapan ini, menggunakan metode ceramah, metode ini dilakukan dengan memberikan pembelajaran langsung melalui ceramah didepan kelas.oleh para dosen yang melakukan pengabdian.

2. Question and answer (tanya jawab)

Pada kegiatan ini dilakukan tanya jawab untuk mengetahui gambaran secara detail pemahaman materi yang baru disampaikan sehingga dapat memberikan umpan balik tentang materi yang baru diajarkkan kepada tutor taman pinter di LBB taman pintar.

3. Assignment (Pemberian tugas)

Pada kegiatan ini masing-masing tutor diberikan tugas untuk membuat assessment hasil belajar sesuai dengan mata pelajaran pada kelompok belajarnya secara mandiri. Peserta yang kesulitas bisa langsung melakukan konsultasi hingga menghasilkan produk assessment hasil belajar seperti yang diharapkan.

\section{PELAKSANAAN DAN PEMBAHASAN}

\section{Pra. Pelatihan}

Pada tahan ini dilakukan dengan membuat rencana kegiatan pelatihan yang melibatkan semua dosen yang terlibat dalam PPM. Pada tahap ini dilakukan observasi tentang sasaran kegiatan, selanjutnya penetapan tempat kegiatan abdimas, dan membuat materi pelatihan, serta membuat instrumen penilaian kegiatan. Kegiatan abdimas kali ini menentukan sasaran kegiatan yaitu di Lembaga Bimbingan Belajar Taman Pintar, Sahabat Sekolah Anak yang merupakan di bawah naungan Yayasan Taman Pintar. Ada 3 cabang di Kecamatan Lamongan, di Kecamatan Tikung, Lamongan dan di Kabupaten Tuban. Jumlah keseluruhan tutor adalah sebagai berikut :

\begin{tabular}{|l|l|c|}
\hline No & \multicolumn{1}{|c|}{ Tutor } & Jumlah \\
\hline I & Taman Pintar I & 20 \\
\hline 2 & Taman Pintar2 & 18 \\
\hline 3 & Taman Pintar3 (Tuban) & 20 \\
\hline & JUMLAH & 58 \\
\hline
\end{tabular}

Tabel I Jumlah Tutor Taman Pintar, Sahabat Sekolah Anak

\section{Pelaksanaan Pelatihan}

Pelatihan dilakukan di Taman Pintar I, Jl. Basuki Rahmad 160 Lamongan pada tanggal 2 Juni - 24 Juni 202I (selama 2 minggu) di hari Sabtu dan minggu. Hari ini dipilih karena pelaksanaan pembelajaran di Taman Pintar semua cabang libur baik secara online, offline maupun home visite.

Pelaksanaan kegiatan dilakukan dengan metode pembelajaran langsung dimana nara sumber menjelaskan didepan materi yang diajarkan kepada tutor Taman Pintar. Kegiatan ini dilakukan dengan presentasi melalui media power point dengan peserta mendengarkan pemaparan materi dari nara sumber selanjutnya kegiatan dilakukan dengan tanya jawab untuk mengatahui tingkat penyerapan materi. 
Pelatihan Merancang Asesmen Hasil Belajar di LBB Taman Pintar Lamongan

Hadi Suryanto, Yayuk Chayatun Machsunah, Ratna Nurdiana

Vol. 1, No. 2, Agustus 2021 hal. 123-129

DOI Artikel : 10.46306/jub.v1i2.27

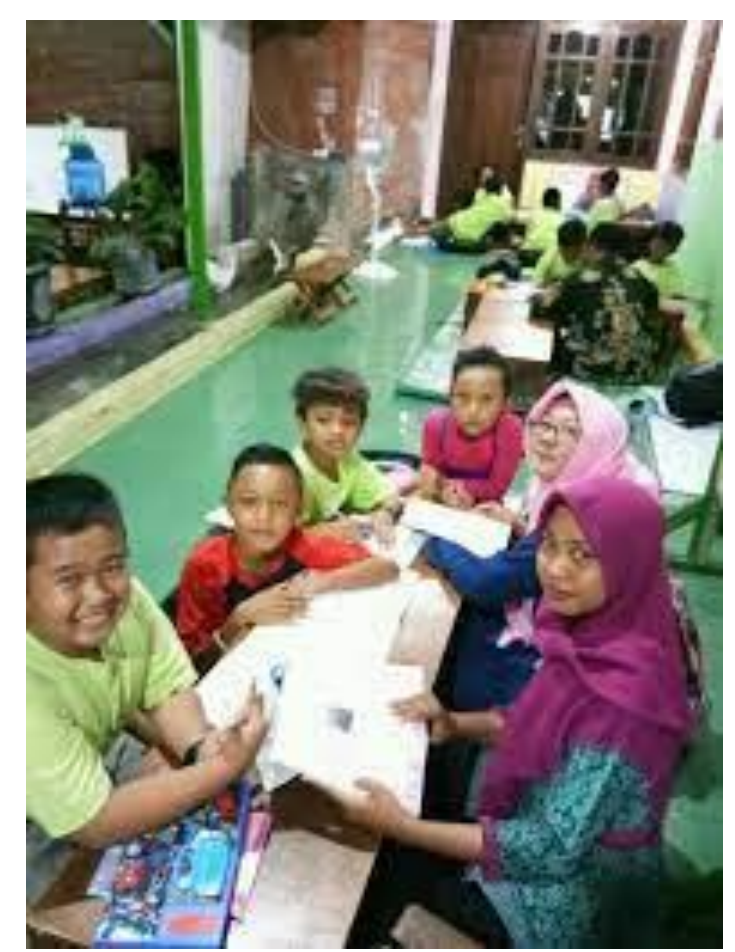

Gambar I. Tutor melakukan pratek asesmen

Hasil pelatihan diperoleh seperti pada tabel dibawah ini .

\begin{tabular}{|r|c|c|c|c|c|}
\hline No. & $\begin{array}{c}\text { Kejelasan } \\
\text { kalimat }\end{array}$ & $\begin{array}{c}\text { Kesesuaian } \\
\text { dengan } \\
\text { materi }\end{array}$ & $\begin{array}{c}\text { Kesesuaian } \\
\text { bentuk } \\
\text { asesmen }\end{array}$ & $\begin{array}{c}\text { Bahasa } \\
\text { mudah } \\
\text { dimengerti }\end{array}$ & Total \\
\hline 1 & 4 & 5 & 5 & 4 & 18 \\
\hline 2 & 4 & 4 & 5 & 5 & 18 \\
\hline 3 & 4 & 4 & 4 & 4 & 16 \\
\hline 4 & 4 & 4 & 4 & 4 & 16 \\
\hline 5 & 4 & 4 & 4 & 4 & 16 \\
\hline 6 & 4 & 4 & 4 & 4 & 16 \\
\hline 7 & 4 & 4 & 4 & 4 & 16 \\
\hline 8 & 4 & 4 & 4 & 4 & 16 \\
\hline 9 & 4 & 5 & 4 & 4 & 17 \\
\hline 10 & 4 & 4 & 4 & 4 & 16 \\
\hline 11 & 4 & 4 & 4 & 4 & 16 \\
\hline 12 & 4 & 4 & 4 & 4 & 16 \\
\hline 13 & 4 & 4 & 4 & 4 & 16 \\
\hline 14 & 4 & 4 & 5 & 5 & 18 \\
\hline 15 & 4 & 4 & 4 & 4 & 16 \\
\hline 16 & 4 & 4 & 5 & 5 & 18 \\
\hline 17 & 4 & 4 & 5 & 5 & 18 \\
\hline 18 & 4 & 4 & 5 & 5 & 18 \\
\hline 19 & 4 & 4 & 5 & 5 & 18 \\
\hline 20 & 4 & 4 & 4 & 4 & 16 \\
\hline
\end{tabular}


Pelatihan Merancang Asesmen Hasil Belajar di LBB Taman Pintar Lamongan

Hadi Suryanto, Yayuk Chayatun Machsunah, Ratna Nurdiana

Vol. 1, No. 2, Agustus 2021 hal. 123-129

DOI Artikel : 10.46306/jub.v1i2.27

\begin{tabular}{|c|c|c|c|c|c|}
\hline 21 & 4 & 4 & 4 & 4 & 16 \\
\hline 22 & 4 & 4 & 4 & 4 & 16 \\
\hline 23 & 4 & 4 & 4 & 4 & 16 \\
\hline 24 & 4 & 4 & 4 & 4 & 16 \\
\hline 25 & 4 & 4 & 4 & 4 & 16 \\
\hline 26 & 4 & 4 & 4 & 4 & 16 \\
\hline 27 & 4 & 4 & 4 & 4 & 16 \\
\hline 28 & 4 & 4 & 5 & 4 & 17 \\
\hline 29 & 4 & 4 & 4 & 4 & 16 \\
\hline 30 & 4 & 4 & 4 & 4 & 16 \\
\hline 31 & 4 & 4 & 4 & 4 & 16 \\
\hline 32 & 4 & 4 & 4 & 4 & 16 \\
\hline 33 & 4 & 4 & 4 & 4 & 16 \\
\hline 34 & 4 & 4 & 4 & 4 & 16 \\
\hline 35 & 4 & 4 & 4 & 4 & 16 \\
\hline 36 & 4 & 4 & 4 & 4 & 16 \\
\hline 37 & 5 & 4 & 4 & 5 & 18 \\
\hline 38 & 4 & 4 & 4 & 4 & 16 \\
\hline 39 & 5 & 4 & 4 & 5 & 18 \\
\hline 40 & 4 & 4 & 4 & 4 & 16 \\
\hline 41 & 4 & 4 & 4 & 4 & 16 \\
\hline 42 & 4 & 4 & 4 & 4 & 16 \\
\hline 43 & 4 & 4 & 4 & 4 & 16 \\
\hline 44 & 5 & 4 & 4 & 4 & 17 \\
\hline 45 & 4 & 4 & 4 & 4 & 16 \\
\hline 46 & 5 & 4 & 4 & 4 & 17 \\
\hline 47 & 4 & 4 & 4 & 4 & 16 \\
\hline 48 & 5 & 4 & 4 & 4 & 17 \\
\hline 49 & 4 & 4 & 4 & 4 & 16 \\
\hline 50 & 4 & 4 & 4 & 4 & 16 \\
\hline 51 & 4 & 4 & 4 & 4 & 16 \\
\hline 52 & 4 & 5 & 5 & 4 & 18 \\
\hline 53 & 4 & 4 & 4 & 4 & 16 \\
\hline 54 & 4 & 4 & 4 & 4 & 16 \\
\hline 55 & 4 & 4 & 4 & 4 & 16 \\
\hline 56 & 5 & 4 & 4 & 4 & 17 \\
\hline 57 & 4 & 4 & 4 & 4 & 16 \\
\hline 58 & 4 & 4 & 4 & 4 & 16 \\
\hline 60 & 238 & 235 & 241 & 240 & 954 \\
\hline
\end{tabular}

Tabel 2 Tanggapan responden

Hasilnya diproleh untuk pada item kejelasan kalimat pertanyaan diperoleh nilai rata-rata 4,I atau bisa dijelaskan bahwa peserta pelatihan mampu membuat kalimat dengan jelas butir-butir asesmen. Item yang kedua yaitu kesesuaian dengan materi diperoleh nilai rata-rata 4 yang berarti kesesuaian butir-butir 
Pelatihan Merancang Asesmen Hasil Belajar di LBB Taman Pintar Lamongan

Hadi Suryanto, Yayuk Chayatun Machsunah, Ratna Nurdiana

Vol. 1, No. 2, Agustus 2021 hal. 123-129

DOI Artikel : 10.46306/jub.v1i2.27

pertanyaan dalam asesmen sesuai dengan materi yang diajarkan. Ketiga kesesuaian bentuk asesmen dengan tujuan pembelajaran diperoleh nilai rata-rata 4.15 ini merupakan nilai rata-rata paling tinggi sehingga bentuk asesmen sesuai dengan tujuan pembelajaran yang hendak dicapai. Item yang ke empat tentang bahasa yang mudah dimengerti diperoleh nilai rata-rata 4.13 artinya bahwa bahasa yang digunakan dalam butir pertanyaan tidak bermakna ganda serta mudah untuk dipahami.

\section{Evaluasi}

Kegiatan pada tahap ini dibagi pada 2 tahap yaitu reflesi dan evaluasi. Pada tahap refleksi digunakan untuk merefleksi ulang kegiatan dari awal sampai akhir, termasuk melakukan pengayaan bila dianggap kegiatan kurang maksimal. Selanjutnya evaluasi pada tahap ini dilakukan evaluasi dari semua tahapan yang sudah dilaksanakan sehingga diperoleh hasil dan manfaat kegiatan abdimas serta sebagai bahan pelaksanaan kegiatan abdimas yang akan datang. Dari hasil evaluasi secara menyeluruh kegiatan pelatihan berjalan dengan baik, tingkat partsipasi peserta juga tinggi hal ini dibuktikan dengan hasil pelatiahan semua peserta memperoleh nilai rata-rata baik dalam pembuatan instrumen asesmen.

\section{KESIMPULAN DAN SARAN}

Asesmen sangat penting untuk mengukur tingkat ketutasan hasil belajar, oleh karena itu pembuatan instrumen asesmen pembelajaran membutuhkan keahlian tersendiri agar tujuan asesmen sesuai dengan tujuan yang diharapkan. Melalui pelatihan melakukan asesmen bagi tutor taman pintar sangat bermanfaat bagi mereka. Antusias peserta yang sangat besar menunjukkan bahwa memang kegiatan ini sangat dibutuhkan bagi mereka karena mereka merupakan tutor taman pintar masuh dalam pendidikan non formal, sehingga mereka harus mampu mengembangkan instrumen asesmen untuk memaksimalkan proses pembelajaran yang mereka lakukan.

\section{UCAPAN TERIMAKASIH}

Ucapan terima kasih kami sampaian kepada Rektor Universitas PGRI Adi buana surabaya, Seluruh pimpinan Universitas PGRI Adi buana surabaya,Tim pengababdian masyarakat dan dosen yang terlibat serta tutor Taman pintar.

\section{DAFTAR PUSTAKA}

Arsyad, Azhar ,(200II) Media Pembelajaran, Jakarta: Rajawali Press,

Asmidi, A. (2020). Pembelajaran Kooperatif Berbantuan Alat Peraga Untuk Meningkatkan Pemahaman Matematika Siswa. Jurnal Pembelajaran Prospektif, 4(2). doi:I0.264I8/jpp.v4i2.40494

Baharudin, (2010) Teori Belajar \& Pembelajaran, Yogyakarta: ArRuzz Media,

Balitbang Depdiknas. (2006). Panduan Penilaian Berbasis Kelas. Jakarta: Depdiknas

Baxter, J., \& John, A. (202I). Strategy as learning in multi-academy trusts in England: strategic thinking in action. School Leadership and Management. https://doi.org/ / 0.1080/I3632434.2020.1863777

Endang Purwati, DKK (2008), assesmen pembelajaran SD. Direktorat Jendral Pendidikan Tinggi, Jakarta: depdiknas

Hustandi, Cecep, (20II) Media Pembelajaran Manual dan Digital, Bogor: Ghalia Indonesia,

Kipman, U., Kühberger, A., \& Pletzer, B. (2019). Activity-oriented teaching of stochastics in elementary school. British Journal of Educational Psychology, 89(I), I3 I-I45. https://doi.org/I0.I I I //bjep. I 2226

Lubis, N. (20I5). Peningkatan Aktivitas Belajar Matematika Dengan Menggunakan Alat Peraga Di Kelas VI SD Negeri 088 Panyabungan Kabupaten Mandailing Natal. School Education Journal Pgsd Fip Unimed, 4(2), 32-42. doi: I0.24II4/sejpgsd.v4i2.36I8

Suryanto, H., Degeng, N. S., Djatmika, E. T., \& Kuswandi, D. (2020). The Effect of Creative Problem Solving Learning Strategy on Conceptual and Procedural Understanding Moderated by Social Skills. 
Pelatihan Merancang Asesmen Hasil Belajar di LBB Taman Pintar Lamongan

Hadi Suryanto, Yayuk Chayatun Machsunah, Ratna Nurdiana

Vol. 1, No. 2, Agustus 2021 hal. 123-129

DOI Artikel : 10.46306/jub.v1i2.27

In International Journal of Innovation, Creativity and Change. www.ijicc.net (Vol. 13). Retrieved from www.ijicc.net 